\title{
Road Traffic Accidents in Ghana: A Public Health Concern, and a Call for Action in Ghana, (and the Sub-Region)
}

\author{
Albert Coleman \\ Centre for Bioethics, Medical Law and Patient Advocacy, Sekondi, Ghana \\ Email: albert.coleman@gmail.com \\ Received 15 September 2014; revised 17 October 2014; accepted 4 November 2014 \\ Copyright (C) 2014 by author and Scientific Research Publishing Inc. \\ This work is licensed under the Creative Commons Attribution International License (CC BY). \\ http://creativecommons.org/licenses/by/4.0/

\section{Abstract}

This paper highlights the increasing problem of road traffic accident (RTA) related morbidity and mortality in Ghana, and the public health measures needed to control the problem. Descriptive data in the public domain from statutory bodies and media houses reports on country RTA information, as well as academic papers on the problem, were used as source of information about the problem. The observed trend in Ghana indicates that RTA related fatalities and injuries continue to be increasing, as morbidity and mortality factors since the year 2000 . Most of the remedial measures suggested in academic papers, and state agencies measures to curb the RTA trend in Ghana to date, have discussed the problem in terms of injury and safety issues/measures. This paper suggests that the increasing RTAs with associated morbidity and mortality in Ghana need to be looked at more as a public health problem and priority that requires prompt tackling using a public health problem orientated approach and measures, than just as a safety problem due to RTAs', as is currently done.

\section{Keywords}

Ghana, Road Traffic Accident (RTA), Fatalities, Public Health, Safety

\section{Introduction}

Road traffic accidents (RTAs) affect populations all over the world; different local factors influence the causes of RTA in specific regions. The causes of RTAs' among others include human or driver errors, vehicle characteristics, traffic infrastructures including engineering design, road maintenance and traffic regulation [1]. Driver attitude including road courtesy and behaviour [2], driving under the influence of drugs especially alcohol, male sex, use of seat belts, driver age (teenage drivers and elderly drivers) etc. [1], are among the recognised human 
factors. It is thought that globally 1.4 million people are killed in RTAs and about 20 million to 50 million people are injured or disabled from the effect of RTAs. Unchecked, by the year 2020, RTAs will rank third of all causes of morbidity and mortality globally [3]-[6]. Of worry though is that RTA related fatalities seem to increase with gross domestic product (GDP) per capita in lower income countries (including Ghana) and decrease with GDP per capita in wealthy countries [7].

Globally the economic impact of RTAs is relatively huge. It is estimated that US \$518 billion is spent globally on RTAs', with US \$65 billion being spent in low and middle income countries (LAMIC), this amount being reported as spent in LAMIC being bigger than what these countries receive per year, in development aid [3]. The public heath impact of RTAs' prompted the world health organisation (WHO) to focus attention in 2004 on a global campaign to curb this growing public health burden [8].

\section{RTA Problem in Ghana}

Ghana is not immune from this public health problem [5] [9] [10]. In large part the local dailies and news media provide coverage of RTAs of a large scale [11]. Other times regional or national road safety commission officials popularise the problem through the news media or local public forums, when commenting on end of year RTA data [12] [13]. This coverage on its own does not give a clear national picture of the health burden of RTAs. A national road safety report of 2007 indicated that at least six people are killed daily in RTAs. This report recognised that $25 \%$ of pedestrian fatalities involve children, $60 \%$ of RTAs can be attributed to speeding and five regions, (Ashanti, Eastern, Greater Accra, Central and Western) account for $80 \%$ of the recorded RTAs [14].

The logical question is, apart from speeding as a recognised factor in RTAs in Ghana, what other principal factors contribute to this problem? Vehicular factors, cannot be ignored, granted the commissioning of the driver and vehicle licensing agency (DVLA) as a statutory body in Ghana; rigorous yearly car inspection is not a norm, as for example is the norm in developed economy countries. Many Ghanaians abroad or returning home from overseas, as well as used car dealers in Ghana import used cars from Europe to use or sell.

Some of these vehicles are just under ten years old, these along with the number of ever increasing old cars already in the country continuously swell the numbers of old cars in the country (in comparison with new cars). Older vehicles are relatively prone to safety defects and accidents [15], the absence of a proper yearly assessment of their mechanical safety and maintenance status, makes the aged vehicles a contributory factor of RTAs. The state and maintenance of roads is a problem in the country. On a road trip even on principal roads in cities, or roads linking principal towns one is confronted with multiple potholes. Intermittent unpaved sections, or sections requiring major works, as well as the issue of impact of poor drainage on road structures, are recognised as contributory to RTAs. Human factors as earlier mentioned, contribute to RTAs in Ghana; these include the driver factor [16] and other human factors as vehicular use enforcement personnel, (including policemen, DVLA personnel, customs staff, magistrates) etc. Driver characteristic has been recognised as a major factor in RTAs. Illiteracy impacting on lack of, or poor understanding of the road code, driving under the influence of alcohol and or cannabis, knowingly overloading vehicles (especially commercial drivers); blatant disregard of the road code, bribing of enforcement personnel (in cases of traffic infringement), road rage, unlicensed drivers and speeding are some of the driver associated factors in Ghana having an effect on RTAs [17]. When it comes to the effect of vehicular traffic regulation on RTAs, a major troubling factor is the issue of corruption especially in the police service [18] and in public life [19]. This is a pervasive problem which is serious, in that it undermines the whole exercise of vehicle and driver regulation. This due to the ease of drivers knowingly bribing their way out of infringement situations, hence setting up scenarios for flaunting the driving code, leading to accidents.

Lack of adequate personnel capacity in the enforcement agencies constitutes another issue facing the enforcement sector in a lot of developing countries including Ghana [5]. This factor impacts on the adequate and exact documenting of facts, and collection of data to derive appropriate statistics to inform decision-making. This last point in the case of data collection or availability is highlighted as a drawback in developing countries; a good number of these countries are yet to meet adequately the Marrakech action Plan for Statistics (MAPS), a meaningful statistical data for national programme planning [20].

\section{Discussion}

Ghana like most low and middle income (LAMIC) especially in the sub-Saharan region, has to pre-occupy itself 
not only with the communicable diseases pervasive in most tropical developing countries; but additionally with other chronic diseases until recently linked mostly to developed countries. This in addition to other health and safety issues of public health importance like RTAs, occupational diseases linked to industrialization etc.; all these impacting on the meagre health budget allocation. For Ghana, RTAs' and the associated morbidity and mortality from all indications are here to stay; so far as the population continuous to grow, and people increasingly own and use motor vehicles. It is sad to note from the official statistics of the National Road Safety Commission (NRSC), Ghana presented in the auditor general's report (Figure 1), that mortality trend from RTAs has been rising consistently from 2000 through 2006. The available data showed a progressive increase in RTA related total fatalities per year from 1578 in 2000 to 1856 in the year 2006, (except for the year 2004, when the number of fatalities was outstandingly high, 2185) [14]. The RTA trend continued to rise additionally from the years 2007 to 2011, as per NRSC report.

The very high number of fatalities in 2004 was attributed to election year electioneering activities. One paper on RTA epidemiology in Ghana indicated pedestrians stand out as a vulnerable group, constituting more than $40 \%$ on the average of the annual crash fatalities, Of note $65.16 \%$ of the pedestrians killed in RTAs occurring in the period 2001-2011, were in the age range 1 - 40 years old [21]. Additionally males predominated females among the fatalities, the months of April, May and August through December showed increased numbers of RTAs' with rates peaking particularly around December (related to the Christmas related activities). Among vehicle categories, cars caused the most accidents, followed by buses [21]. Since the publication of the data from Figure 1, the trend from 2007 through 2011 has been similar [14] [21].

The head of the Ghana national road safety commission, in analysing national RTA trend in Ghana from 2000-2012 at a public forum, is quoted as saying RTA fatalities in Ghana is worse compared to death from diseases in that period [22]. This perception of Ghana 2000-2012 RTA trend and impact, is again re-enforced in a recent published paper [23].

From a health and safety point of view, what could be done to stem the gradually rising morbidity and mortality associated with RTAs in Ghana? Various measures have been recognised and tested which granted not specifically directed at the factors contributory to the Ghana situation listed above, clearly will impact positively and help stem this health and safety problem. Driver behaviour and education can be highly influenced by targeted health promotion campaigns [24]. Seat belts, alcohol and drug regulation and monitoring [1] [25]-[27] are definite know preventive interventions. Pedestrian education and protection, especially for the LAMIC sphere like Ghana, should be given due attention [28].

Attention to development and maintenance of strategically placed emergency response and trauma centres for timely attendance to RTA victims to reduce morbidity and mortality is important [4] [29]. Additionally appropriate capacity building in the areas of road and transportation enforcement and regulatory bodies/personnel, legislation and data collection and management among others, count greatly towards containing this important health and safety problem [5].

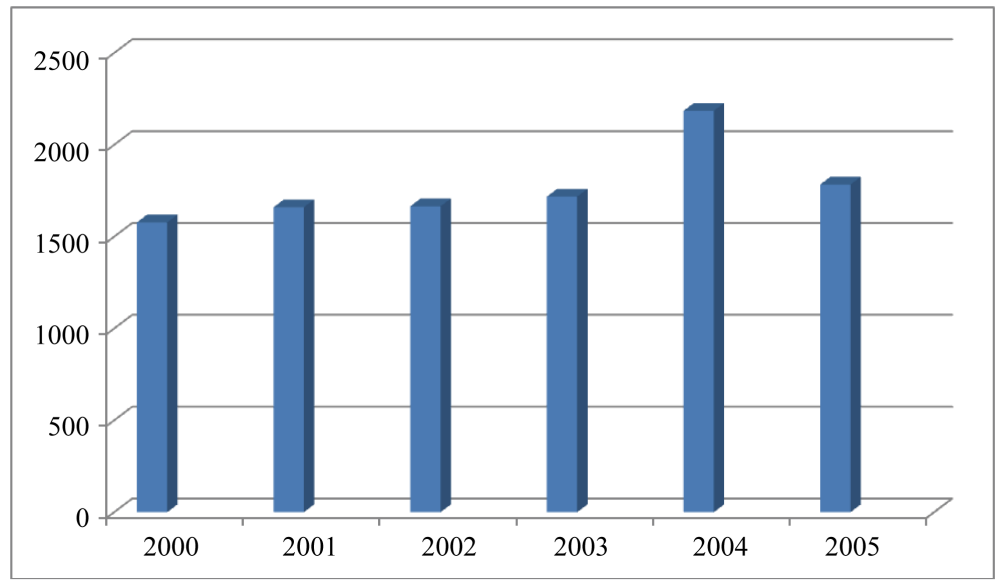

Figure 1. Ghana: road traffic fatalities. 2000-2005. Legend: Horizontal axis = calendar years. Vertical axis = number of fatalities. Data source: National road safety committee. 
RTAs' are a problematic but preventable source of population morbidity and mortality, with costly implications both for victims and on national health budgets [3] [5]. RTAs result in killing and maiming, and more important it is preventable. Health services are about maintaining well-being, but additionally preoccupies as well with death, maiming and above all prevention of such. Here lies the premise for a leading role for health in the inter-agency effort to curb RTAs and the effects of RTAs, especially in developing countries including Ghana. Prevention of, not management of the after effects of RTAs, is considered the thrust of control of RTAs'; and national public health agencies have been identified as major movers in this direction [7] [28]-[30]. In the case of Ghana, much of what has been written about RTAs is either written by transportation engineers or planners, and/or with trauma surgeons [5] [8] [9] [31] [32], or the local media [10] [33] [34]. On the other hand neither the Ministry of health nor the national medical community has been seen to engage in a concerted sustained public health campaign to stem the enduring problem of RTAs' or related fatalities.

This not even when three Ghanaian doctors including a renowned urology professor fell victim to the road carnage, in the course of rendering specialist service to deprived regions of the country [34]. In public health terms, this was a missed opportunity for the medical community and the health ministry to step up to the plate and rally and sustain an enduring national RTA prevention awareness and prevention campaign then.

There have been a few articles on post-RTA emergency hospital care (or no care) in Ghana [35], an after the fact issue compared to prevention education, or risky behaviour change through health promotion campaigns. This lack of a preventive health or public health approach to this growing public health problem might be due to the fact that issues like RTAs or occupational safety and health matters are not considered health related diseases in Ghana and some LAMIC, but rather attributable to the wrath of a deity [28]. This despite the fact that in countries considered at the forefront of having being able to curb the incidents of RTAs' and related deaths, their success was attributed to well managed public health initiatives [28] [29]. RTAs are in many ways related to attitudinal or behaviour or life style attributes [36] [37]. From a public health perspective in considering factors affecting the health of populations, Blum has identified four main factors-genetic, environmental, behavioural/ lifestyle and health services that impact on health outcomes [38]. Except for genetic factors, environmental, behavioural and health services factors impact directly on RTAs. Hence public health initiatives for prevention and containment of RTAs in Ghana need to focus on these as they affect RTAs [39]. These interventions including among others traffic technology and human factor attributes, have been used and applied with success in developed countries [24] [25] [28] [29]; more so as vehicle driver behaviour is a major contributory factor [15].

Politically governments in developing countries including Ghana need to provide the executive (and legislative) backing and direction, towards prevention and control of RTAs' [40], especially backing to enforcement and health services; in line with Blum's paradigm mentioned earlier. This again will go a long way in bringing the country in the long run at par with positive gains, as has been achieved in control of RTAs and its effects in most developed countries [25] [28]-[30]. This last point is very important if one considers that comparatively in a five year period (2000-2005) in England and Wales, considering trends in fatal accidents for each year considered, there were ten times more such death per year in Ghana compared to England and Wales [41]. This is shocking for a country with relatively more cars, and a population just about three times that of Ghana.

Talk and published papers alone cannot remedy the RTA problem, along with its public health implications in Ghana. The population should be cognitively prepared and willing to act to effect change in that direction, as without such a national will for change in that direction, probably little could be achieved in that respect. Considering what it entails to successfully and effectively effect behavioural change [42]. This last point is important as in considering the year 2007 despite some mass media highlighting of the RTA problem in Ghana, the road carnage in the country continued with high fatalities being recorded, especially for single event accidents [33]. Most Western countries have been confronted with similar RTA related problems as Ghana faces, and have been able to come up with appropriate public health measures to contain the problem to a large degree. The jury and experience gained is there for the taking [28]-[30] and Ghana can learn and adopt the tried measures elsewhere in the developed economy countries, by "thinking globally, yet acting locally"; (to borrow from David Brower) [43]. The building blocks for developing a comprehensive national public health road safety programme can be developed around the principle of the Haddon matrix of motor vehicle injury prevention [44]. Using the host, agent and environment (rows), and the pre-event, event and post-event (columns) as a template, an effective programme can be developed to hopefully address and cut down the scourge of RTA in Ghana. 


\section{Conclusion}

RTA related fatalities and injuries continue to be an important morbidity and mortality problem, as well as a health finance problem in Ghana requiring urgent attention and containment as has been done in some countries with developed economies [28]-[30]. The problem of RTAs' in Ghana though must not be seen and managed through the lens of "RTAs' being just a safety issue", and hence being tackled as such; as has been reflected in the public domain in the past. What this paper particularly stresses and brings to the Ghana RTA discussion, is that the problem of RTA containment should primarily focus on prevention by utilising a multifaceted public health approach. This approach draws on all the relevant public health disciplines of epidemiology, statistics, environmental sciences, behavioural sciences, safety and injury prevention, health services administration and others, as well as the incorporation of emergency and advanced trauma support services, to guide and formulate policies towards containing the scourge of the RTA problem currently confronting the country. Of note in ending this manuscript is that the problem of RTAs in Ghana is not typical of Ghana only, but a problem in the sub-region and Sub-Saharan Africa in general [45] [46]. Hence the public health implications and solutions discussed above apply as much to Ghana, as well as other countries in the Sub-Saharan region. The urgency for containment of the RTA situation in Ghana (and the Sub-Saharan region) is especially important now; more so as the United Nations considers the problem of RTA containment a global public health priority, and has declared the decade 2011 to 2020 as the "decade of action for road safety" [47].

\section{Competing Interests}

Nothing to declare.

\section{References}

[1] Bjerre, J., Kirkebjerg, P.G. and Larsen, L.B. (2006) Prevention of Traffic Deaths Involving Motor Vehicles. Ugeskrift for Lager, 168, 1764-1768.

[2] Smart, R.G. and Mann, R.E. (2002) Death and Injuries from Road Rage: Cases in Canadian Newspapers. Canadian Medical Association Journal, 167, 761-762.

[3] Peden, M. (2005) Global Collaboration on Road Traffic Injury Prevention. International Journal of Injury Control and Safety Promotion, 12, 85-91. http://dx.doi.org/10.1080/15660970500086130

[4] Hazen, A. and Ehiri, J.E. (2006) Road Traffic Injuries: Hidden Epidemic in Less Developed Countries. Journal of the National Medical Association, 98, 73-82.

[5] Mock, C., Kobusingye, O., Anh, L.V., Afukaar, F. and Arreola-Risa, C. (2005) Human Resources for the Control of Road Traffic Injury. Bulletin of the World Health Organisation, 83.

[6] WHO (2014) Global Status Report on Road Safety 2013. WHO Press, Geneva. www.who.int/violence_injury_prevention/road_safety_status/2013/en/

[7] Bishai, D., Quresh, A., James, P. and Ghaffar, A. (2006) National Road Casualties and Economic Development. Health Economics, 15, 65-81. http://dx.doi.org/10.1002/hec.1020

[8] WHO and World Bank (2004) World Report on Road Traffic Injury Prevention. WHO, Geneva.

[9] Salifu, M. and Mock, C.N. (1998) Pedestrian Injuries in Kumasi: Results of an Epidemiologic Survey. The Ghana Engineer, 18, 2-3.

[10] London, J., Mock, C.N., Abatanga, F.A., Quansah, R.E. and Boateng, K.A. (2002) Using Mortuary Statistics in the Development of an Injury Surveillance System in Ghana. Bulletin of the World Health Organisation, 80, 357-364.

[11] Donkor, K.B. (2014) 21 Dead in Accra-Kumasi Highway Accident. Graphic Online. http://graphic.com.gh/news/general-news/29846-21-dead-in-accra-kumasi-highway-accident.html

[12] Ghanaweb.com. Road Accident Record Scary. http://www.ghanaweb.com/GhanaHomePage/NewsArchive/artikel.php?ID=260266\#

[13] Ghanaweb.com. Group Predicts More Road Accidents unless... http://www.ghanaweb.com/GhanaHomePage/NewsArchive/artikel.php?ID=201825

[14] Auditor Generals Department, Ghana. Performance Audit of the Auditor General on Road Safety in Ghana. www.ghaudit.org/gas/site/reports/download-report/20

[15] Blows, S., Ivers, R.Q., Woodward, M., Connors, J., Ameratunga, S. and Norton, R. (2000) Vehicle Year and the Risk of Car Crash Injuries. Injury Prevention, 9, 353-356. http://dx.doi.org/10.1136/ip.9.4.353 
[16] Evans, L. (1996) The Dominant Role of Driver Behaviour in Traffic Safety. American Journal of Public Health, 86, 784-786.

[17] Ghanaweb.com. NRSC Launches First UN Global Road Safety Week. http://www.ghanaweb.com/GhanaHomePage/NewsArchive/artikel.php?ID=122893

[18] Ghanaweb.com. Police Service the Most Corrupt Public Institution in Ghana-Report. http://www.ghanaweb.com/GhanaHomePage/NewsArchive/artikel.php?ID=279056

[19] Ghanaweb.com. Face up to End Corruption-Prof Mensah-Bonsu. http://www.ghanaweb.com/GhanaHomePage/NewsArchive/artikel.php?ID=122804

[20] International Development Association (2004) Measuring Results: Improving National Statistics in IDA Countries. IDA14, PG 2.

[21] Amo, T. and Meirmanov, S. (2014) The Epidemiology of Road Traffic Accident (RTA) in Ghana, 2001-2011. Life Science Journal, 11, 269-275. www.lifesciencesite.com/lsj/life110914_269_275.pdf

[22] Appiah, S. (2013) Daily Graphic/Ghana. Road Accidents Killing More than Diseases. http://graphic.com.gh/news/general-news/14621-road-accidents-killing-more-than-diseases.html

[23] Siaw, N.A., Duodu, E. and Sarkordie, S.K. (2013) Trends in Road Traffic Accidents in Ghana; Implications for Improving Road User Safety. International Journal of Humanities and Social Science Invention, 2, 31-35. www.ijssh.org

[24] Smith, W.A. (2006) Social Marketing: An Overview of Approach and Effects. Injury Prevention, 12, i38-i43. www.injuryprevention.bmj.com http://dx.doi.org/10.1136/ip.2006.012864

[25] McKay, M. (2004) Traffic Safety in the United States. American Journal of Public Health, 94, 170-171.

[26] Khiabani, H.Z., Christophersen, A.S. and Morland, J. (2007) Cannabis Affects Driving Skills. Tidsskrift for Den Norske Legeforening, 127, 583-584.

[27] Council on Scientific Affairs (1986) Alcohol and the Driver. Council on Scientific Affairs. Journal of the American Medical Association, 255, 522-527. http://dx.doi.org/10.1001/jama.255.4.522

[28] Dahl, R. (2004) Vehicular Manslaughter: The Global Epidemic of Traffic Deaths. Environmental Health Perspectives, 112, A626-A631.

[29] Pless, B. (2004) Road Traffic Accident Prevention. British Medical Journal, 328, 846. http://dx.doi.org/10.1136/bmj.328.7444.846

[30] Evans, L. (2003) A New Traffic Safety Vision for the United States. American Journal of Public Health, 93, 13841386. http://dx.doi.org/10.2105/AJPH.93.9.1384

[31] Afukaar, F.K., Antwi, P. and Ofosu-Amaah, S. (2003) Pattern of Road Traffic Injuries in Ghana: Implications for Control. Injury Control and Safety Promotion, 10, 69-76. http://dx.doi.org/10.1076/icsp.10.1.69.14107

[32] Derry, J.D., Afukaar, F.K., Donkor, P. and Mock, C. (2007) Study of Vehicle Speeds on a Major Highway in Ghana: Implications for Monitoring and Control. Traffic Injury Prevention, 8, 142-148. http://dx.doi.org/10.1080/15389580601100944

[33] Ghanaweb.com. Death Toll in Winneba Accident Now at 40. http://www.ghanaweb.com/GhanaHomePage/rumor/artikel.php?ID=123882

[34] Ghanaweb.com. Korle-Bu Mourns. General News of Friday. http://www.ghanaweb.com/GhanaHomePage/NewsArchive/artikel.php?ID=89073

[35] Mock, C., Arreola-Risa, C. and Quansah, R. (2003) Strengthening Care for Injured Persons in Less Developed Countries: A Case Study of Ghana and Mexico. Injury Control and Safety Promotion, 10, 45-51. http://dx.doi.org/10.1076/icsp.10.1.45.14114

[36] Mesken, J., Lajunen, T. and Summala, H. (2002) Interpersonal Violations, Speeding Violations and Their Relation to Accident Involvement in Finland. Ergonomics, 45, 469-483. http://dx.doi.org/10.1080/00140130210129682

[37] Parker, D., West, R., Stradling, S. and Manstead, A.S. (1995) Behavioural Characteristics and Involvement in Different Types of Traffic Accidents. Accident Analysis \& Prevention, 27, 571-581. http://dx.doi.org/10.1016/0001-4575(95)00005-K

[38] Blum, H.L. (1983) Expanding Health Care Horizons from a Generalized Concept of Health to a National Policy. Third Party Publishing Co., Oakland, 34-37.

[39] Fordjuoh, S.N. (2003) Traffic-Related Injury Prevention Interventions for Low-Income Countries. Injury Control and Safety Promotion, 10, 109-118. http://dx.doi.org/10.1076/icsp.10.1.109.14115

[40] Fordjuoh, S.N., Zwi, A.B. and Mock, C.N. (1998) Injury Control in Africa: Getting Governments to Do More. Tropical Medicine \& International Health, 3, 349-356. http://dx.doi.org/10.1046/j.1365-3156.1998.00240.x 
[41] Ward, H., Christie, N., Lyons, R., Broughton, J., Clarke, D. and Ward, P. (2007) Road Safety Research Report No. 76: Trends in Fatal Car-Occupant Accidents. Department for Transport, London.

[42] Prochaska, J.O. and Di Clemente, C.C. (1983) Stages and Processes of Self-Change: Toward an Integrative Model of Change. Journal of Consulting and Clinical Psychology, 51, 390-395. http://dx.doi.org/10.1037/0022-006X.51.3.390

[43] Friends of the Earth. FOE Mourns Death of Founder. Press Release. www.foe.co.uk/resource/press_release/2001107obit

[44] Haddon, W. (1972) A Logical Framework for Categorizing Highway Safety Phenomena and Activity. Journal of Trauma, 12, 193-207. http://dx.doi.org/10.1097/00005373-197203000-00002

[45] Lagarde, E. (2007) Road Traffic Injury Is an Escalating Burden in Africa and Deserves Proportionate Research Efforts. PLoS Medicine, 4, 170. http://dx.doi.org/10.1371/journal.pmed.0040170

[46] World Health Organisation (2009) Global Status Report on Motor Vehicle Safety: Time for Action. WHO, Geneva.

[47] UN Decade of Action for Road Safety. Ensuring the Decade Is Action.

http://www.makeroadssafe.org/publications/Documents/decade_is_action_booklet.pdf 
Scientific Research Publishing (SCIRP) is one of the largest Open Access journal publishers. It is currently publishing more than 200 open access, online, peer-reviewed journals covering a wide range of academic disciplines. SCIRP serves the worldwide academic communities and contributes to the progress and application of science with its publication.

Other selected journals from SCIRP are listed as below. Submit your manuscript to us via either submit@scirp.org or Online Submission Portal.
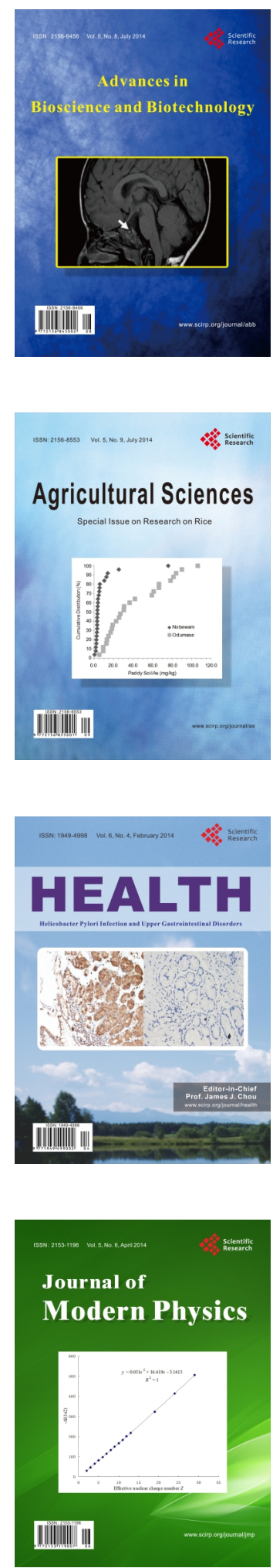
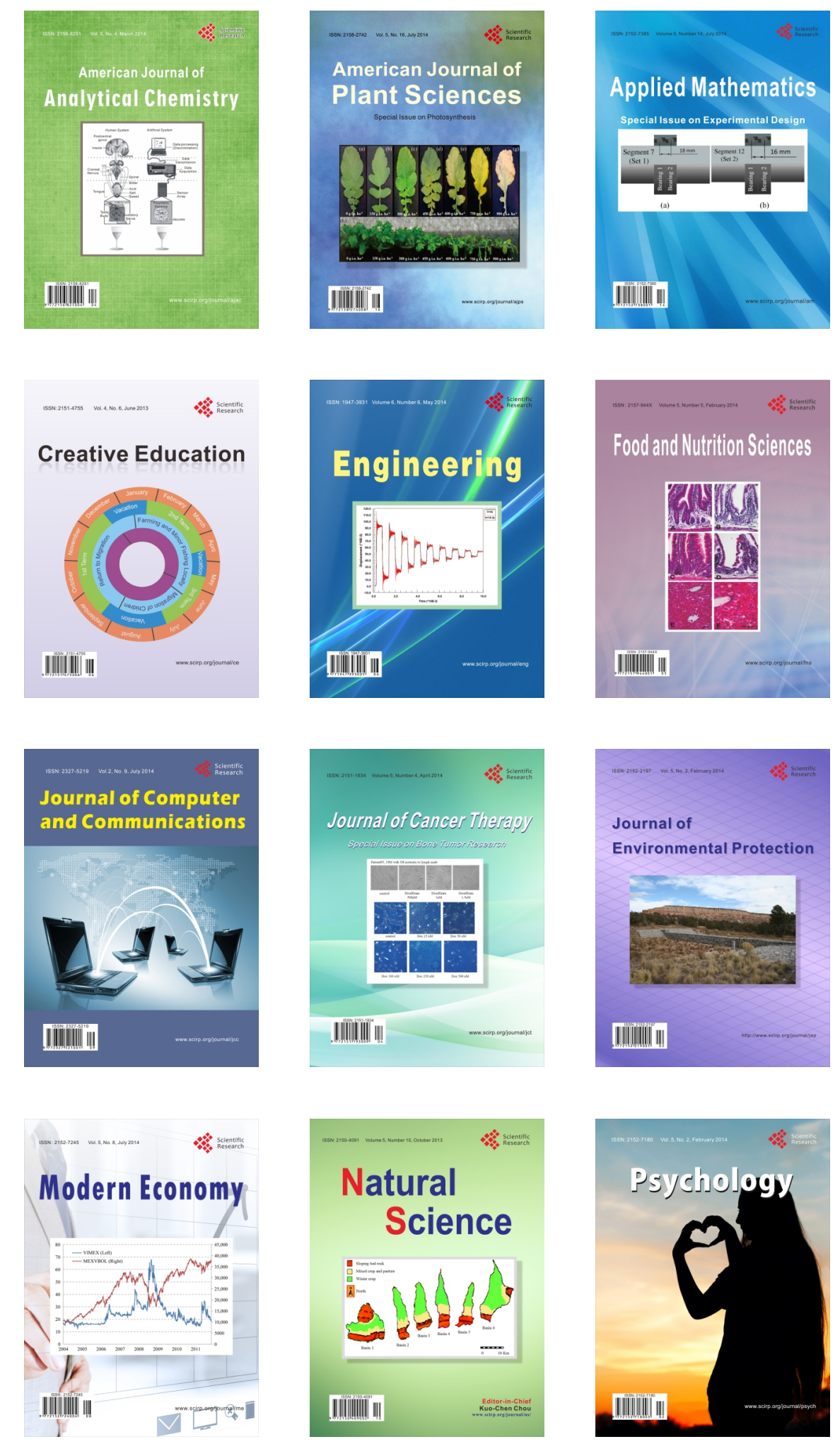